\title{
Hydro-climatic Variability and Trend Analysis of Modjo River Watershed, Awash River Basin of Ethiopia
}

\author{
Melat Eshetu \\ Ethiopian Institute of Agricultural Research, Melkassa Agricultural Research Center, \\ P.O. Box 436, Adama, Ethiopia
}

\begin{abstract}
Climate change and variability is expected to trigger changes in temperature and precipitation series. This study aimed at assessing variability and trend of hydro-climatic variables at Modjo River watershed. Long-term climate data of 5 representative stations with in the watershed (1981-2010) and streamflow data of Modjo gauging station (1983 -2010) were used. Rainfall variability was analyzed using Coefficient of variation (CV), Precipitation concentration index (PCI) and Standardized anomaly index (SAI). Climate trends were evaluated using Sen's slope estimator and Mann-Kendall trend test methods. The study revealed Most of the stations showed low variation in annual rainfall $(\mathrm{CV} \%<20)$ while the main (Kiremt) and short $($ Belg) season rainfall exhibited $\mathrm{CV}$ ranging from low to high. Both annual and seasonal rainfall showed a non-significant trend at all stations for the past 30 years. However, majority of stations showed an increasing trend in annual daily average temperature ranging from 0.2 to $0.6^{\circ} \mathrm{C}$ per decade. Following increases in temperature and the subsequent rise in evapotranspiration, streamflow has shown a high significant declining trend. The temporal decline in streamflow at Modjo watershed could likely affect downstream Koka dam water reserve. Thus, any watershed management strategy that can optimize water conservation for sustainable crop production and option that can improve flow to the reserve is vital.
\end{abstract}

Keywords: Climate change, Climate variability, Hydro-climate, trend, Modjo river watershed

DOI: $10.7176 / \mathrm{JEES} / 11-9-04$

Publication date:September $30^{\text {th }} 2021$

\section{Introduction}

Climate is a vital natural resources on the earth which can be seen as the major backbone of all the water resources, and is one of the key variable that affect both the spatial and temporal pattern of water resources (Fentaw et al., 2017). African continent exhibits higher inter-annual and intra-seasonal climate variability(Boko et al., 2007). Ethiopia is one among countries most vulnerable to climate variability and change (Thornton et al., 2006).

Climate change has contributed to climate variability and change in the frequency and intensity of extreme events. IPCC has showed that the historical climate record for Africa shows warming about $0.7{ }^{0} \mathrm{C}$, and a decrease in rainfall over large portions of the Sahel (IPCC, 2007). Similar reports also revealed that, in Ethiopia warming has occurred at variable rates but broadly consistent with global and African trends and rainfall has showed both an increasing and decreasing trend in different areas of the country (NMA, 2007).

Climate variability and change appears to have a very marked effect on many hydrological series (Kundzewicz and Robson, 2004). Streamflow is mainly vulnerable to rainfall and temperature, and changes in their pattern which have a direct impacts on streamflow change and variability (Kumar et al., 2010). Increased evaporation, combined with changes in precipitation, has the potential to affect streamflow, the frequency and intensity of floods and droughts, soil moisture, and available water for irrigation and hydroelectric generation (Setegn et al., 2011).

Trend and variability analysis of rainfall and temperature series is necessary for agriculture production, energy production, drinking water supply, and management and utilization of resources (Bekele et al., 2016). Trend and variability analysis in precipitation and temperature series have been investigated by many researchers in Ethiopia, Ademe et al.(2019) for the Great Rift Valley Basins of Ethiopia, Bekele et al.(2016) for Keleta watershed of Awash River Basin, Muluneh and Biazin(2015) in the Central Rift Valley of Ethiopia, Mengistu et al.(2014) in the Upper Blue Nile River Basin of Ethiopia, Tekle and Tadele(2014) in Bilate watershed of Ethiopian rift valley, Kassie et al.(2013) in the Central Rift Valley of Ethiopia, Setegn et al.(2011) in Lake Tana Basin and Abdo et al.(2009) in Gilgel Abay Catchment of Abay Basin, The reports agree that, temperature showed an increasing trend and except for few stations, no significant trend in the annual rainfall pattern was observed for the majority of stations studied and most of the studies indicated there is a variability in rainfall. Tibebe et al. (2019) indicated that there is a variability of rainfall and streamflow whereas an increasing trend of streamflow was observed in most of the stations within Awash river basin.

Even though many research's have been conducted most of them has focused on trend and variability analysis of rainfall considering only the yield aspect. Even though (Tibebe et al., 2019; Gedefaw et al., 2018; Gizaw et al., 2017) has studied the hydrologic aspect still in a broader scale of Awash River basin not considering the specific condition. For instance Tibebe et al. (2019) associated the streamflow at Modjo gauging station with only rainfall from Modjo station whereas there are four other station which are not considered but covering the larger area of 
the watershed and have immense contribution to the stream flow. Thus there is a need to understand the temporal and spatial variation of hydro-climatic variables in a watershed scale since Modjo River watershed is major tributary to Koka dam, changes in any of the hydro-climatic variables in the watershed thus pose a great challenge. (Biru and Kumar, 2016). The objective of the present study were to understand and characterize the variability and trend of the hydro-climatic variables in the study periods.

\section{MATERIALS AND METHODS}

\subsection{Study Area Description}

Modjo River watershed having a total area of $1984.96 \mathrm{~km}^{2}$ is situated in the upper Awash River basin of Ethiopia (Figure 1). Geographically it is located between latitudes of $8^{\circ} 25^{\prime} \mathrm{N}$ and $9^{\circ} 07^{\prime} \mathrm{N}$ and longitude of $38^{\circ} 50^{\prime} \mathrm{E}$ and $39^{\circ} 17^{\prime} \mathrm{E}$. The watershed drains to Modjo river then to Koka dam and finally into Awash River. An altitude ranging from $1590 \mathrm{~m}$ asl at the river bed to above $3000 \mathrm{~m}$ a.s.l at the upper part characterize the watershed (Biru and Kumar, 2016). The watershed is characterized by bimodal rainfall pattern with picks in April and July. More than $80 \%$ of the annual rainfall is received during June to September (locally known as Kiremt) whereas the short season extends from February/March to May (locally known as Belg). The total annual rainfall of the watershed is $940 \mathrm{~mm}$. The mean maximum temperature of the watershed is ranging from $21^{\circ} \mathrm{C}$ to $27^{\circ} \mathrm{C}$ (Biru and Kumar, 2016). The watershed is dominated by agricultural land use. According to FAO the major dominant soil types of the watershed is Pellic Vertisol(FAO/UNESCO, 1995).

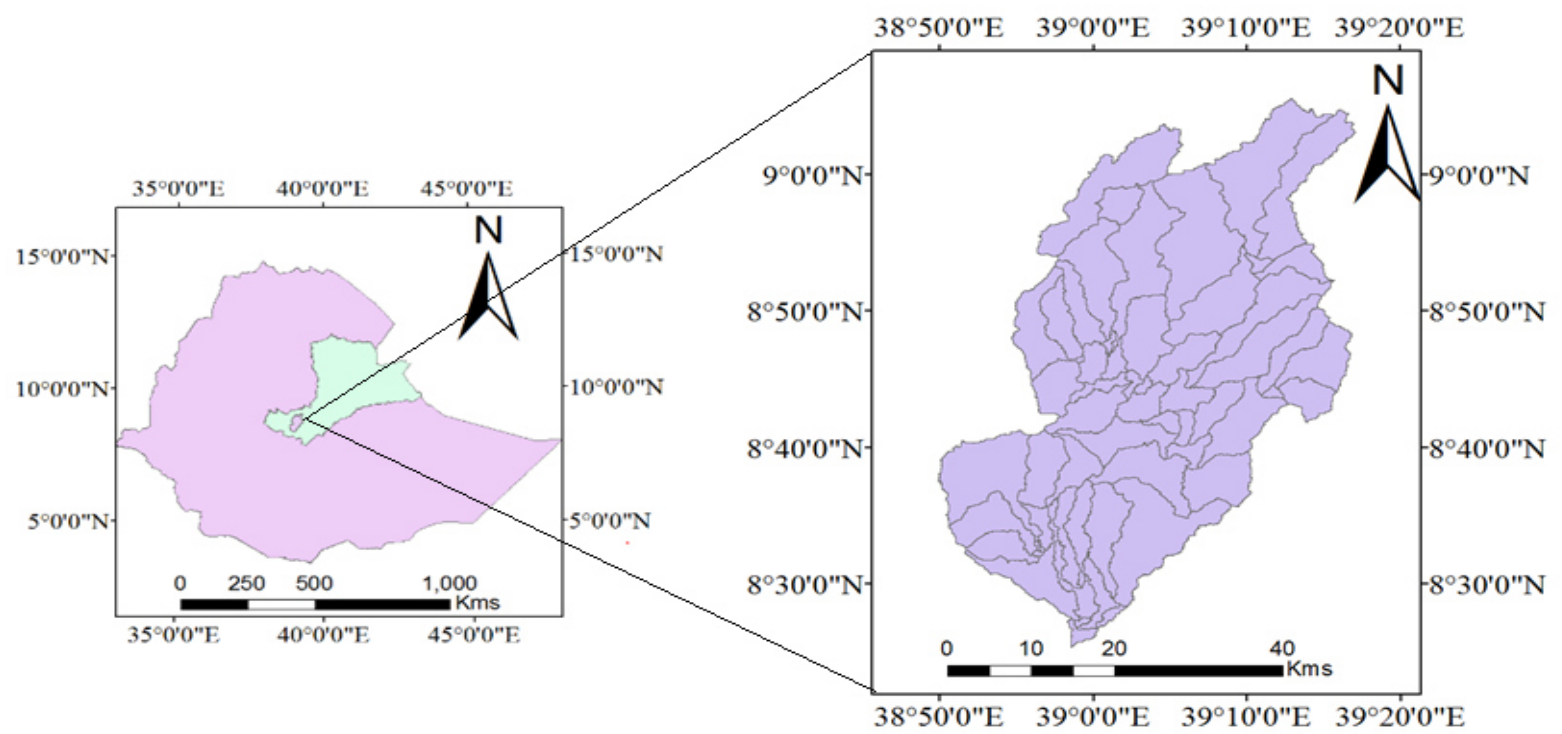

Figure 1. Location of the study area

\subsection{Methodology}

\subsubsection{Data source}

Daily meteorological variables such as daily rainfall, daily maximum and minimum temperature, has been collected from National Meteorology Agency (NMA) for stations present in the watershed boundary for the period 1981-2010 (http://www.ethiomet.gov.et). The data were selected, which have relatively long periods of data records(at least 30 years) and have no more than 10\% missing values based on Seleshi and Zanke (2004). Similarly, streamflow data of Modjo gauging station (1983 -2010) was obtained from ministry of water, irrigation and electricity of Ethiopia.

\subsubsection{Data quality assessment}

Data quality was ensured for presence of outliers, homogeneity and missing data before using the time series climate data for further analysis. Climate data collected from each station has been arranged and outlier has been detected following Tukey fence method (Ngongondo et al., 2011). The outliers were then culled out from the analysis. Similarly, most of the long-term climatic time series can be affected by number of non-climatic factors which make the data unrepresentative of actual climate variations occurring over time (Peterson et al., 1998). Thus observed data taken from weather stations should be tested for reliability and homogeneity before they are utilized. The cumulative deviation test was used to detect inhomogeneity in the meteorological time series data(details of the description are available in: Bekele et al., 2016; Ngongondo et al., 2011;Buishand, 1982). According to Buishand(1982), the data series was examined for homogeneity and no heterogeneity was detected for this study. Negative daily rainfall records and temperature data with daily maximum value less than the daily minimum value were removed and considered as missing values. Missing data in time series were then re-filled using first order 
Markov chain model with INSTAT plus (v 3.37) software (Stern et al., 2006) before using it for further analysis.

\subsubsection{Hydro meteorological variability analysis}

The temporal variability of rainfall and discharge for the study watershed(representative meteorological stations) was determined by three commonly used statistical rainfall variability descriptors. The coefficient of variation $(\mathrm{CV})$, which is the ratio of the standard deviation to the mean in a given period is useful when interest is in the size of variation relative to the size of the observation. In comparing different years of rainfalls with different means, the $\mathrm{CV}$ is a more useful basis of comparison than the standard deviation(Equation 1). The precipitation concentration index was employed to investigate monthly distribution of rainfall (Equation 2). Inter-annual variability was evaluated using standardized anomalies (SAI) with respect to the long-term average conditions for a specific time scale (Equation 3).Different studies have used this methods to describe variability (Ademe et al., 2019; Bekele et al., 2016; Kassie et al., 2013;Bewket and Conway, 2007). The variability descriptors can be written as:

$C V=\left[\frac{S}{X}\right] * 100$

where $S$ and $X$ denote standard deviation and long term mean of rainfall, respectively. In this study, a $C V$ of $<20 \%$, between $20-30 \%$, and $>30 \%$ was considered as low, moderate and highly variable, respectively.

$$
\mathrm{PCI}=\frac{\sum p i^{2}}{\left(\sum p i\right)^{2}} * 100
$$

Where, $\mathrm{Pi}$ is the rainfall amount of the ith month. PCI values of less than 10 indicate uniform monthly rainfall distribution in the year, whereas values from 11 to 20 denote seasonality in rainfall distribution. PCI values above 20 correspond to substantial monthly variability in rainfall amounts(Bewket and Conway, 2007).

$S A I=\frac{x-\mu}{\sigma}$

Where $x$ is the annual rainfall, $\mu$ is long term mean annual rainfall over the period of observation and $\sigma$ is the standard deviation of annual rainfall. Positive normalized rainfall anomalies indicate greater than long-term mean rainfall, while negative anomalies indicate less than the mean rainfall. When averaged over several stations, the normalized rainfall anomaly yields anormalized rainfall anomaly index.

\subsubsection{Trend analysis}

Trend was tested using Mann-Kendall's and Sen's Slope estimator tests for annual, Kiremt and Belg seasons of the study watershed for the period of 1981 to 2010. Both Mann-Kendall's and Sen's Slope test are none parametric test (Yue et al., 2002,Salmi et al., 2002; Kendall, 1975; Mann, 1945,).The Mann-Kendall test is based on the test statistic S defined as follows (Yue et al., 2002).

$$
S=\sum_{i=1}^{n-1} \sum_{j=i+1}^{n} \operatorname{sgn}(X j-X i) \ldots \ldots \ldots \ldots \ldots \ldots \ldots \text { for } j>i
$$

Where the $\mathrm{X}_{\mathrm{j}}$ and $\mathrm{X}_{\mathrm{i}}$ are the sequential data values, $\mathrm{n}$ is the length of the data set, and

$\operatorname{sgn}\left(X_{j}-X_{k}\right)=\left\{\begin{array}{c}1 \text { if }\left(X_{j}-X_{k}\right)>0 \\ 0 \text { if }\left(X_{j}-X_{k}\right)=0 \\ -1 \text { if }\left(X_{j}-X_{k}\right)<0\end{array}\right\}$

Mann (1945) and Kendall (1975) have documented that when $\mathrm{n} \geq 8$, the statistic $\mathrm{S}$ is approximately normally distributed with the mean and the variance as follows. $E(S)=0$

$$
V(S)=\frac{n(n-1)(2 n+5)-\sum_{m=1}^{n} t i(m-1)(2 m+5) m}{18}(6)
$$

Where $t_{i}$ is the number of ties of extent $i$. The standardized test statistic $Z$ is computed by

$$
\mathrm{Z}= \begin{cases}\frac{\mathrm{S}-1}{\sqrt{\operatorname{Var}(\mathrm{S})}} & \text { if } \mathrm{S}>0 \\ 0 & \text { if } \mathrm{S}=0 \\ \frac{\mathrm{S}+1}{\sqrt{\operatorname{Var}(\mathrm{S})}} & \text { if } \mathrm{S}<0\end{cases}
$$

The standardized Mann-Kendall statistic $Z$ follows the standard normal distribution with mean of zero and variance of one. In Sen's Slope test true slope of a trend is estimated, Sen's test is used when the trend is assumed to be linear. Sen's Slope is computed by (Salmi et al., 2002).

$\mathrm{F}(\mathrm{t})=\mathrm{Q}_{\mathrm{t}}+\mathrm{b}$

Where $\mathrm{f}(\mathrm{t})=$ increasing or decreasing function of time, $Q=$ the slope, $B=$ intercept (constant) The slope of each data pair $Q_{i}$ is calculated as:

$$
Q i=\frac{X j-X k}{j-k}
$$


Were, $\mathrm{j}>\mathrm{k}$ and, if there is $\mathrm{n}$ number of in the time series, we get as many as $\mathrm{N}=\frac{\mathrm{n}(\mathrm{n}-1)}{2}$

\section{RESULT AND DISCUSSION}

\subsection{Climatic characteristics of Modjo River watershed}

The monthly rainfall distribution of stations situated at Modjo River watershed is shown in Figure2. The mean monthly rainfall distribution of all the representative stations follow a bimodal rainfall pattern picks in April (Belg) and July (Kiremt).About $72 \%$ of the rainfall is received during Kiremt (June to September) in the watershed. Monthly distribution of total rainfall received in the watershed varies widely from as small as $3.5 \mathrm{~mm}$ for the driest month(December) at Modjo station to $290.7 \mathrm{~mm}$ for the wettest month (July) at Aleltu. The mean annual distribution of rainfall within the watershed ranges from $1040 \mathrm{~mm}$ in the upstream to $873 \mathrm{~mm}$ in the downstream(Table 1). The annual weighted average rainfall of the study watershed is $950 \mathrm{~mm}$ with an elevated standard deviation of $107 \mathrm{~mm}$ likely resulted from altitudinal variations existed in the watershed. Following variations in elevation, temperature also exhibited variations across the study watershed. The mean annual minimum and maximum temperatures are 9.7 and $25.6^{\circ} \mathrm{C}$, respectively. The mean maximum temperature of the watershed ranges from $24{ }^{\circ} \mathrm{C}$ to $27.6{ }^{\circ} \mathrm{C}$ and the highest being recorded in the month of May and the lowest in August. While the mean minimum temperature ranges from $6.3{ }^{\circ} \mathrm{C}$ to $12.8{ }^{\circ} \mathrm{C}$ the highest being recorded in the month of July and the lowest in the month of December. The annual mean temperature of Modjo river watershed is about $17.6{ }^{\circ} \mathrm{C}$ for the recorded historical period. The Kiremt season has minimum temperatures of 7.5 to $16.5^{\circ} \mathrm{C}$ and maximum temperatures of 19 to $30^{\circ} \mathrm{C}$. For Belg season, the minimum temperature ranges from 6 to $16.4{ }^{\circ} \mathrm{C}$ and the maximum temperature varies from 21 to $33.6{ }^{\circ} \mathrm{C}$. Aligned with this study, Kassie et al.(2013) indicated the annual mean temperature in the $\mathrm{CRV}$ is $18.9^{\circ} \mathrm{C}$ and the annual mean minimum and maximum temperatures are 12 and $26^{\circ} \mathrm{C}$, respectively.
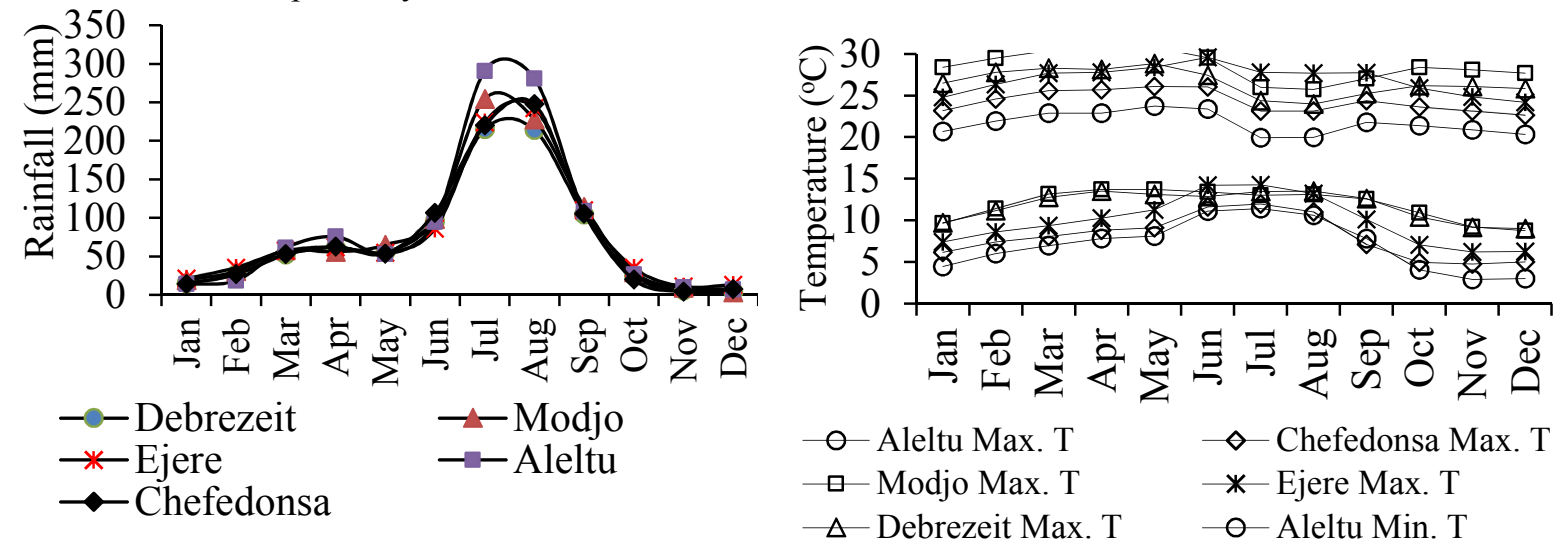

Figure 2. The mean monthly Rainfall, maximum and minimum temperature of Modjo River watershed.

\subsection{Hydro-climatic variability analysis}

Most of the stations showed normal variation in annual rainfall $(\mathrm{CV} \%<20)$ except for Modjo station exhibits moderate variation (CV 26\%). The precipitation concentration index (PCI) value is more than $11 \%$ for all of the stations indicating the seasonality in rainfall distribution(Bewket and Conway, 2007). Normalized rainfall anomaly index calculated for a period of 30 years (1981-2010) for all stations also indicate that the annual rainfall of Modjo river watershed showed both wet and dry conditions with negative anomalies $43.3 \%, 53.3 \%, 50 \%, 53.3 \%$ and $50 \%$ of the years for Debrezeit, Modjo, Ejere, Aleltu and Chefedonsa stations respectively. The coefficient of variation of the main (Kiremt) and short (Belg) season rainfall ranged from low to high. It can be noted that some of the station (Debrezeit and Ejere)showed low variability while (Aleltu, Chefedonsa and Modjo) fall under moderate variability range (20 to 30\%) for June to September rainfall. Unlike Kiremt rainfall of the stations, the Beg seasonal rainfall showed a high degree of variability for all stations The short season is very prone to risk for rain-fed agriculture and almost all of the stations in the study watershed clearly indicate high (43.6 to $61.1 \%$ ) ranges of rainfall variability (Table 1). Similar result has also been found by Ademe et al. (2019, Bekele et al.(2016) and Kassie et al.(2013)emphasized that the causes of annual and seasonal inter-annual variability of precipitation over Ethiopia is due to the forward and retreat pace of the African sector of the intertropical convergence zone (ITCZ). The high variability in Beg rainfall will cause unfavorable condition for agricultural production (Kassie et al., 2013). 
Table 1. Rainfall (mm) variability characteristics of stations within Modjo River watershed, 1981-2010.

\begin{tabular}{|c|c|c|c|c|c|c|c|}
\hline & Annual & & Kiremt & & Belg & & \\
\hline Stations & Mean & $\mathrm{CV}$ & Mean & $\mathrm{CV}$ & Mean & $\mathrm{CV}$ & PCI \\
\hline Aleltu & 1040 & 15.5 & 774.4 & 22.3 & 189.7 & 49.5 & 18.3 \\
\hline Chefedonsa & 922 & 19.6 & 680 & 22 & 169 & 49.4 & 16.8 \\
\hline Debrezeit & 873 & 16 & 629.5 & 17.4 & 169 & 61.1 & 16.1 \\
\hline Ejere & 951 & 17.9 & 662.5 & 16.8 & 173.7 & 52.8 & 15.6 \\
\hline Modjo & 964 & 26.1 & 694.7 & 26.5 & 178.2 & 59.8 & 16.4 \\
\hline Watershed AV. & 950 & 11.3 & 688.2 & 14.8 & 175.9 & 46.3 & 16.6 \\
\hline
\end{tabular}

\subsection{Streamflow characteristics and variability}

The mean monthly Average, maximum and minimum River discharge of Modjo River watershed is shown in (Figure. 3). The mean monthly average discharge was low from November to June, and started to increase in the month of June as the highest flow was recorded in the month of August. The maximum mean discharge was low from mid-November to mid-April and have at least one event maximum flow from mid-April to first days of November. The highest discharge was 91.5, 216.4 and $14.1 \mathrm{~m}^{3} / \mathrm{s}$ (on the month of August) for average maximum and minimum discharge respectively. The lowest record is $0.37 \mathrm{~m}^{3} / \mathrm{s} 0.64 \mathrm{~m}^{3} / \mathrm{s}$ in the month of January, for mean average and maximum discharge and $0.09 \mathrm{~m}^{3} / \mathrm{s}$ in the month of November for minimum discharge respectively.

Table 2. Average, maximum and minimum discharge $\left(\mathrm{m}^{3} / \mathrm{s}\right)$ variability characteristics of Modjo River watershed, 1983-2010.

\begin{tabular}{llllllll}
\hline \multirow{2}{*}{ Variable } & \multicolumn{2}{c}{ Annual } & \multicolumn{2}{c}{ Kiremt } & \multicolumn{2}{c}{ Belg } \\
\cline { 2 - 7 } & \multicolumn{2}{c}{ Mean } & \multicolumn{1}{c}{ CV } & Mean & CV & Mean & CV \\
\hline Maximum Discharge & 268.8 & 40.1 & 266.7 & 41.1 & 56.3 & 118.5 \\
Minimum Discharge & 0.14 & 63 & 0.35 & 55.2 & 0.21 & 115.8 \\
Average & 17.5 & 72.4 & 49.3 & 73.7 & 2.9 & 134.7 \\
Discharge & & &
\end{tabular}

The result of variability analysis in maximum, minimum and average streamflow at Modjo gauging station indicates that there is a high variability $(\mathrm{CV}>30)$ for both annual and seasonal basis. The annual and Kiremt discharge showed relatively medium CV while the Belg discharge showed very high CV (118.5, 115.8 and 134.7) for maximum, minimum and average discharge respectively. Similar study conducted in Awash River Basin has also indicated a very high variability of discharge for both annual and seasonal basis and correlated the variability of discharge with the variability of rainfall (Tibebe et al., 2019).

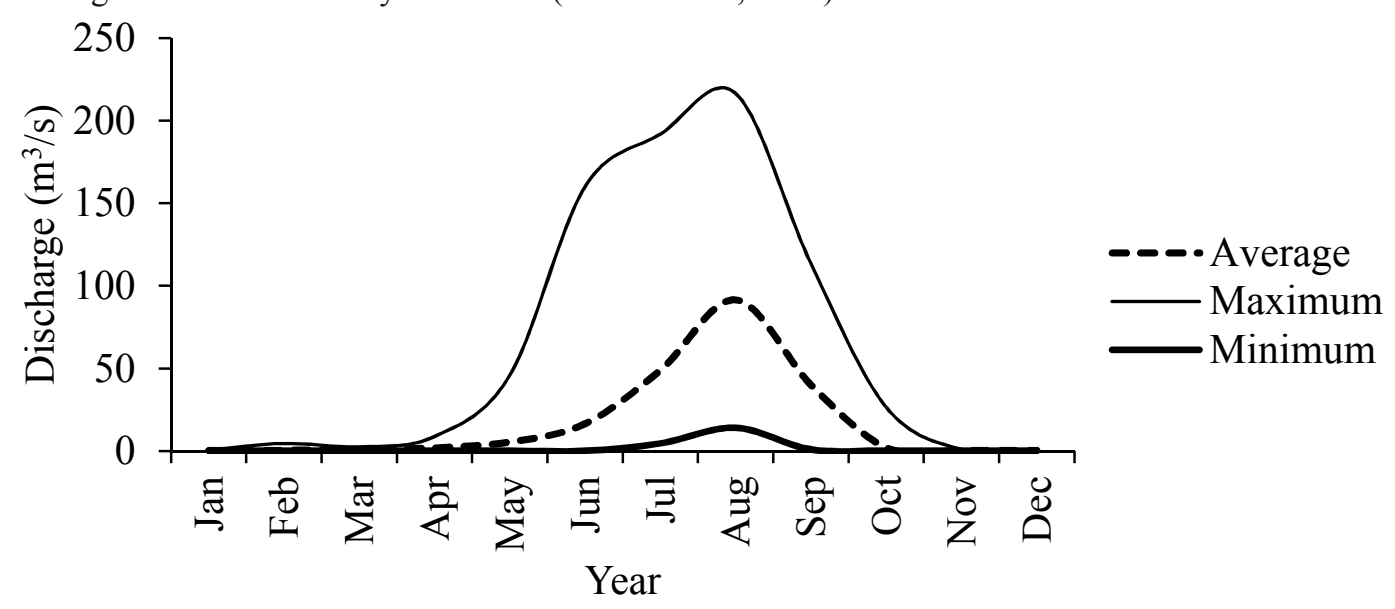

Figure 3. The mean monthly Average, maximum and minimum River discharge of Modjo River watershed

\subsection{Trend Analysis}

\subsubsection{Rainfall}

Analysis of annual, Kiremt and Belg precipitation indicated that none of the stations in the study watershed showed significant increasing or decreasing trend over the last 30 years (1981-2010) (Table 3). The analysis however depicted that a numerical increment in precipitation was observed in three of the stations for annual trend and four of them showed increasing signals in its Kiremt precipitation. The Belg season however showed a non-significant declining trend in precipitation for four of the five representative stations. 
Table 3. Mann-Kendall (Z) and Sen's Slope (Q) trend (mm/year) result for annual, Kiremt and Belg precipitation of stations in Modjo River watershed during 1981 to 2010.

\begin{tabular}{lccccccccc}
\hline & \multicolumn{4}{c}{ Annual } & \multicolumn{3}{c}{ Kiremt } & \multicolumn{3}{c}{ Belg } \\
\cline { 2 - 10 } Station Name & $\mathrm{Z}$ & $\mathrm{Q}$ & $\mathrm{P}-$ Value & $\mathrm{Z}$ & $\mathrm{Q}$ & $\mathrm{P}-$ Value & $\mathrm{Z}$ & $\mathrm{Q}$ & P-Value \\
\hline Aleltu & -0.12 & -4.14 & 0.17 & -0.05 & -1.74 & 0.72 & -0.12 & -2.86 & 0.36 \\
Chefedonsa & 0.07 & 2.91 & 0.61 & 0.10 & 2.12 & 0.44 & 0.07 & 0.56 & 0.61 \\
Debrezeit & 0.04 & 0.76 & 0.76 & 0.06 & 0.86 & 0.65 & -0.13 & -1.94 & 0.33 \\
Ejere & -0.02 & -0.25 & 1.0 & 0.14 & 2.33 & 0.27 & -0.09 & -1.25 & 0.45 \\
Modjo & 0.09 & 2.79 & 0.48 & 0.11 & 3.0 & 0.39 & 0.09 & 1.33 & 0.48 \\
Watershed Av. & 0.14 & 3.85 & 0.26 & 0.17 & 2.64 & 0.19 & -0.00 & -0.03 & 1.0 \\
\hline
\end{tabular}

The rainfall of Aleltu station indicated a decline in trend of rainfall on average 41, 17.4 and $28.5 \mathrm{~mm} / \mathrm{decade}$ respectively for annual, Kiremt and Belg seasons. Similarly, rainfall of Ejere station for annual and Beg season and Debrezeit station for Beg season showed declining trend over the past 30 years. The rest of the stations showed an increasing trend of rainfall for all season. The overall result of weighted rainfall value of Modjo river watershed showed there is an increasing trend of 38.4 and $26.3 \mathrm{~mm} /$ decade of rainfall for annual and Kiremt, respectively. The Belg season however showed a non-significant declining trend during the observed period.

Aligned with this, studies conducted in Central Rift valley of Ethiopia showed, out of the sixteen tested stations the trends of the annual and seasonal rainfall of most of the stations did not showed statistically significant trend for the period of 1977 to 2007 (Kassie et al., 2013). Similarly, Ademe et al.(2019) found only one out of seventeen stations with significant changes in the annual rainfall during the record period for the Great Rift Valley Basins of Ethiopia. They reported however that, the majority of the stations show a non-significant positive trend in the range of 0.66 to $4.25 \mathrm{~mm} / \mathrm{yr}$ and some stations showed a non-significant negative trend ranging from 0.55 to $3.17 \mathrm{~mm} / \mathrm{yr}$. Likewise Bekele et al.(2016) revealed that the direction and magnitude of annual and seasonal rainfall trend was not uniform throughout different stations found in Awash River Basin Ethiopia. Although nonsignificant statistically, the majority of the studies indicated a numerically declining trend of rainfall in most of the tested stations(Ademe et al., 2019;Bekele et al., 2016;Mengistu et al. 2014;Kassie et al., 2013). Mengistu et al.(2014)for instance indicated, a numerically declining trend in rainfall for the Upper Blue Nile River Basin of Ethiopia.

\subsubsection{Temperature}

Unlike precipitation, temperature has showed a statistically very high significant trend $(\mathrm{p} \leq 0.01)$ for all mean annual and seasonal maximum, minimum and average temperatures in the study watershed during 1981-2010 observed periods (Table. 4). The mean annual maximum temperature increased very significantly across all stations in the watershed ranging from $0.2-0.6{ }^{0} \mathrm{C}$ per decade for annual trends. Minimum temperature however showed inconsistent trend across the stations in the watershed. Consequently, Aleltu, Ejere and Chefedonsa experienced a significant increase in minimum temperature $0.5{ }^{\circ} \mathrm{C}$ per decade each while at Modjo, minimum temperature showed a cooling trend of about $0.5{ }^{\circ} \mathrm{C}$ per decade. Debrezeit however didn't show any significant trend for minimum temperature. On a seasonal basis, the Belg maximum temperature increases with the range of 0.4-0.6 ${ }^{0} \mathrm{C}$ and the minimum temperature with $0.01-0.6{ }^{0} \mathrm{C}$ per decade. The Kiremt maximum temperature increased with $0.1-0.8{ }^{0} \mathrm{C}$ per decade and its minimum temperature with $0.2-0.3{ }^{\circ} \mathrm{C}$ per decade. The overall result of the study watershed temperature showed there is an increment trend of both minimum and maximum temperature of Modjo River watershed.

In line with this a study conducted in the Central Rift valley of Ethiopia indicated an increasing trend of temperature ranging from 0.12 to $0.54{ }^{\circ} \mathrm{C}$ per decade for different stations(Kassie et al., 2013). Supporting the finding of this study Meehl et al.(2007)stated the global average temperature has raised by $0.74{ }^{0} \mathrm{C}$ in the last century. IPCC(2007)affirmed the historical climate record for Africa showed warming about $0.7{ }^{0} \mathrm{C}$, and cover most of the continent during the $20^{\text {th }}$ century. Correspondingly, NMA(2007) indicated in Ethiopia temperature has raised consistent with global and African trends. In general, studies conducted in different parts of Ethiopia were proved increases in temperature (Kassie et al., 2013; NMA, 2007) 
Table 4. Mann-Kendall $(\mathrm{Z})$ and Sen's Slope $(\mathrm{Q})$ trend $\left({ }^{0} \mathrm{C} /\right.$ year $)$ result for Annual, Kiremt and Belg temperature of stations in Modjo River watershed during 1981 to 2010.

\begin{tabular}{|c|c|c|c|c|c|c|c|c|c|c|}
\hline \multirow[t]{2}{*}{ Station Name } & \multirow{2}{*}{ Variable } & \multicolumn{3}{|c|}{ Annual } & \multicolumn{3}{|c|}{ Kiremt } & \multicolumn{3}{|c|}{ Belg } \\
\hline & & $\mathrm{Z}$ & $\mathrm{Q}$ & P-value & $\mathrm{Z}$ & $\mathrm{Q}$ & P-value & $\mathrm{Z}$ & $\mathrm{Q}$ & P-value \\
\hline \multirow{2}{*}{ Aleltu } & $T$ _max & 0.48 & 0.06 & $0.00 * *$ & 0.46 & 0.08 & $0.00 * *$ & 0.38 & 0.06 & $0.00 * *$ \\
\hline & $\mathrm{T}_{-}^{-} \min$ & 0.44 & 0.05 & $0.00 * *$ & 0.48 & 0.03 & $0.00 * *$ & 0.39 & 0.05 & $0.00 * *$ \\
\hline \multirow{2}{*}{ Chefedonsa } & T_max & 0.50 & 0.06 & $0.00 * *$ & 0.42 & 0.08 & $0.00 * *$ & 0.41 & 0.06 & $0.00 * *$ \\
\hline & $\mathrm{T}_{-}^{-} \min$ & 0.50 & 0.05 & $0.00 * *$ & 0.37 & 0.03 & $0.00 * *$ & 0.48 & 0.06 & $0.00 * *$ \\
\hline \multirow{2}{*}{ Debrezeit } & T_max & 0.34 & 0.02 & $0.02 * *$ & 0.20 & 0.01 & 0.13 & 0.28 & 0.04 & $0.03 *$ \\
\hline & $\mathrm{T}_{-}^{-} \min$ & 0.03 & 0.01 & 0.81 & 0.23 & 0.02 & 0.07 & 0.01 & 0.001 & 0.95 \\
\hline \multirow{2}{*}{ Ejere } & T_max & 0.45 & 0.05 & $0.00 * *$ & 0.38 & 0.05 & $0.00 * *$ & 0.37 & 0.05 & $0.00 * *$ \\
\hline & T_min & 0.50 & 0.05 & $0.00 * *$ & 0.41 & 0.03 & $0.00 * *$ & 0.49 & 0.05 & $0.00 * *$ \\
\hline \multirow{2}{*}{ Modjo } & T_max & 0.47 & 0.06 & $0.00 * *$ & 0.29 & 0.05 & $0.02 *$ & 0.27 & 0.05 & $0.03 *$ \\
\hline & T_min & -0.29 & -0.05 & $0.00 * *$ & -0.16 & -0.04 & 0.21 & -0.33 & -0.06 & $0.01 * *$ \\
\hline \multirow{2}{*}{ WS Av. } & T_max & 0.53 & 0.06 & $0.00 * *$ & 0.41 & 0.06 & $0.00 * *$ & 0.41 & 0.05 & $0.00 * *$ \\
\hline & T_min & 0.11 & 0.01 & 0.39 & 0.07 & 0.01 & 0.59 & 0.20 & 0.02 & 0.11 \\
\hline
\end{tabular}

** significant at $99 \%$ confidence level, *Significant trend at $95 \%$ confidence level

\subsubsection{Streamflow}

Streamflow trend over time at Modjo River watershed is shown in Table 5. The result of trend analysis in stream flow at Modjo gauging station indicates that there is a highly significant declining trend $(\mathrm{p} \leq 0.01)$ of both annual and Kiremt maximum and mean discharge. The annual minimum discharge showed a non-significant inclining trend, Kiremt minimum showed a significant increasing trend $(\mathrm{p} \leq 0.05)$ and no change was detected for Belg minimum discharge. Considering a significant observed increases in minimum flow during Kiremt would signal exposure of the land through time aggravating water loss from the catchment area. On the other hand, the annual maximum and mean discharge respectively declines by -5.85 and $-0.81 \mathrm{~m}^{3} / \mathrm{s} /$ year and Kiremt maximum and mean discharge decreases by -5.85 and $-2.35 \mathrm{~m}^{3} / \mathrm{s} /$ year, respectively. Similar study conducted at Awash River Basin indicated that decreasing trend for annual and seasonal streamflow at Modjo gauging station (Tibebe et al., 2019). The decreasing trend of discharge in this study may be attributed to a decreasing trend in rainfall at some stations (Aleltu and Ejere) and an increasing trend in temperature along with other factors. Tibebe et al. (2019) suggested the streamflow reduction might be related to climatic factors, environmental change and other factors. Assefa and Moges (2018) also indicated mainly a decrease in streamflow in the Blue Nile Basin is attributed to the catchment dynamics especially land cover change and climate (rainfall and temperature) changes over the river basins. The high significant decreases in annual and Kiremt flow will highly likely impact the sustainability of Koka dam reservoir and needs careful measure.

Table 5. Mann-Kendall (Z) and Sen's Slope (Q) trend $\left(\mathrm{m}^{3} / \mathrm{s}\right)$ result for Annual and seasonal maximum minimum and mean discharge of Modjo River watershed during 1983 to 2010

\begin{tabular}{lllllllllc}
\hline \multirow{2}{*}{ Variable } & \multicolumn{3}{c}{ Annual } & \multicolumn{3}{c}{ Kiremt } & \multicolumn{2}{c}{ Belg } \\
\cline { 2 - 10 } & $\mathrm{Z}$ & $\mathrm{Q}$ & $\mathrm{P}$-value & $\mathrm{Z}$ & $\mathrm{Q}$ & $\mathrm{P}$-value & $\mathrm{Z}$ & $\mathrm{Q}$ & P-value \\
\hline Maximum Discharge & -0.44 & -5.85 & $0.001^{* *}$ & -0.42 & -5.85 & $0.002^{* *}$ & -0.15 & -0.8 & 0.28 \\
Minimum Discharge & 0.07 & 0.001 & 0.62 & 0.28 & 0.005 & $0.037^{*}$ & 0.027 & 0 & 0.85 \\
Mean Discharge & -0.42 & -0.81 & $0.001^{* *}$ & -0.39 & -2.35 & $0.003^{* *}$ & -0.026 & -0.006 & 0.86 \\
\hline
\end{tabular}

** significant at $99 \%$ confidence level, *Significant trend at $95 \%$ confidence level

\subsection{Relationship between hydro-climatic variables \\ 3.5.1 Rainfall vs Discharge}

The relationship between rainfall and cumulative discharge of the watershed is portrayed in Figure 4 . The annual rainfall of the different stations and discharge at Modjo river watershed indicated a positive correlation except at Modjo station. A very low correlation was observed for Ejere $(\mathrm{r}=0.04)$ while the highest was shown for Aleltu $(\mathrm{r}$ $=0.43)$. The average rainfall of the whole watershed showed a positive but relatively weak correlation $(\mathrm{r}=0.22)$ with discharge. Likewise, a very low coefficient of determinations values ranging from $0.16 \%$ at Ejere to $17.8 \%$ at Aleltu was calculated. The low values in coefficient of determination might indicate high unaccounted variations in discharge that could not be explained by rainfall alone. However numerical analysis result indicates that discharge of Modjo river watershed at (Modjo gauging station) is majorly influenced by the rainfall of Aleltu $\left(\mathrm{R}^{2}=17.8 \%\right)$ followed by Chefedonsa $\left(\mathrm{R}^{2}=9.96 \%\right)$ and Debrezeit $\left(\mathrm{R}^{2}=7.15 \%\right)$ than the rest of the stations. The weighted watershed rainfall and discharge has a positive correlation with coefficient of determination $4.89 \%$ which was low implying rainfall amount alone cannot describe variations in stream flow in the watershed. Similar to the result obtained, Milliman et al. (2008) reported trends in annual streamflow for many rivers were driven by changes in precipitation. Other study conducted in Awash River basin also reported a positive correlation between rainfall and streamflow (Tibebe et al., 2019). The direction of streamflow change generally followed the direction of 

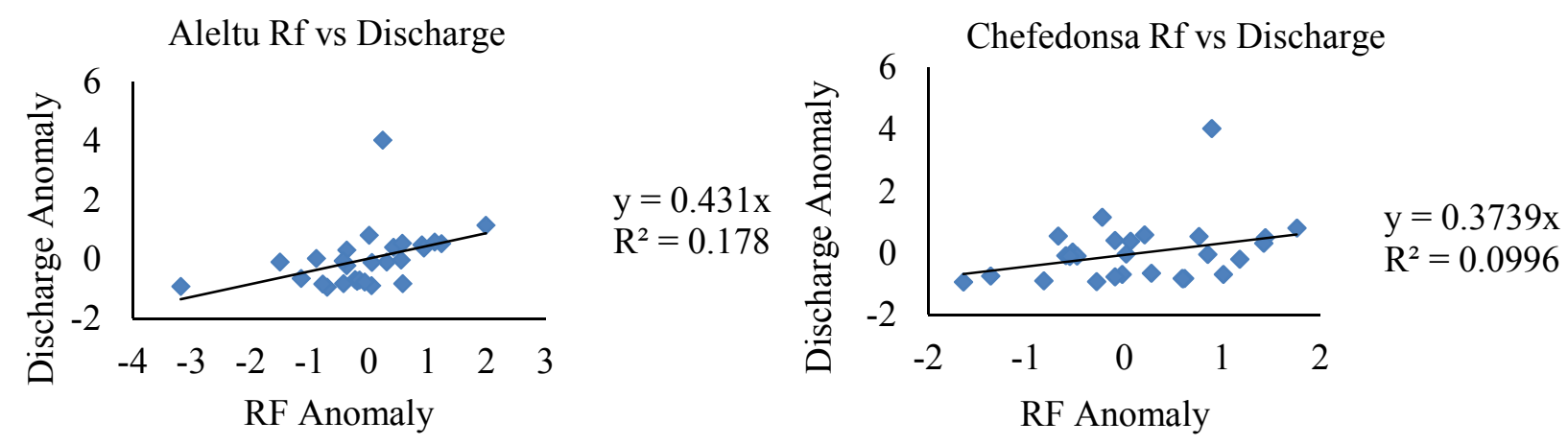

Debrezeit Rf vs Discharge
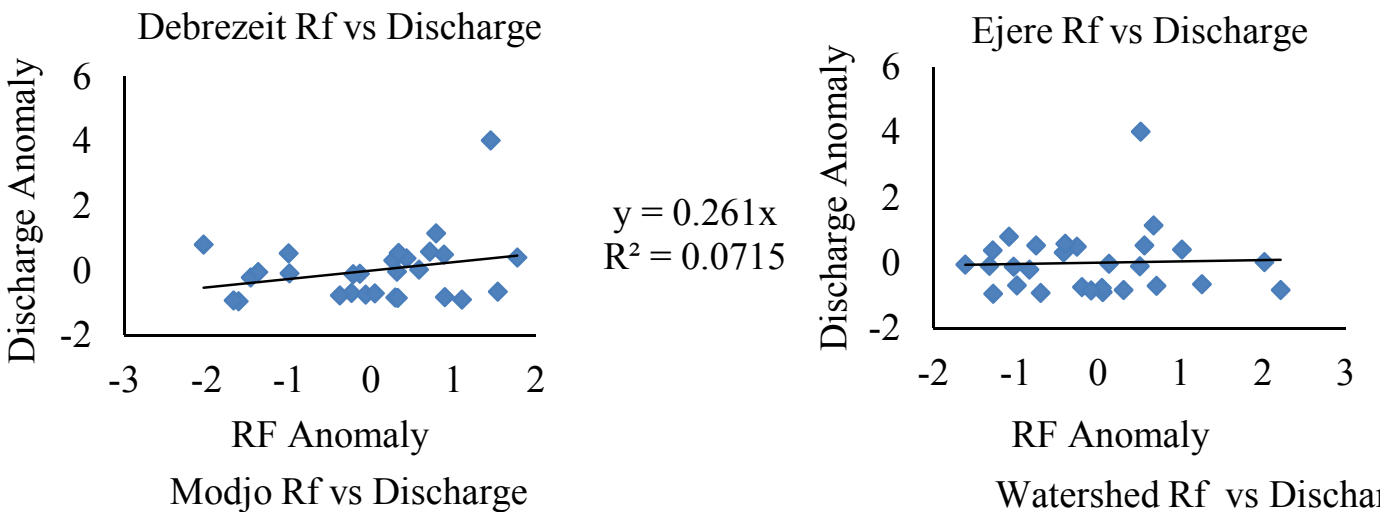

$\mathrm{y}=0.0407 \mathrm{x}$

$\mathrm{R}^{2}=0.0016$

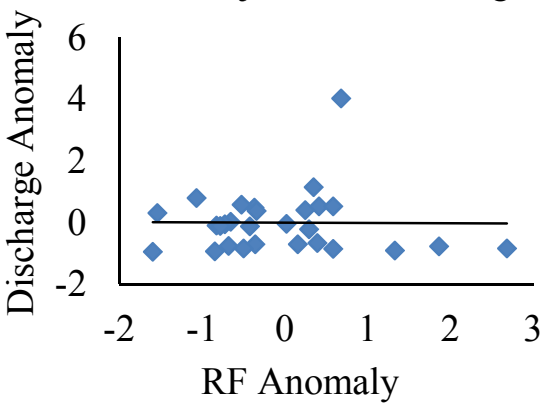

$\mathrm{y}=-0.011 x$

$\mathrm{R}^{2}=0.0001$

Watershed Rf vs Discharge
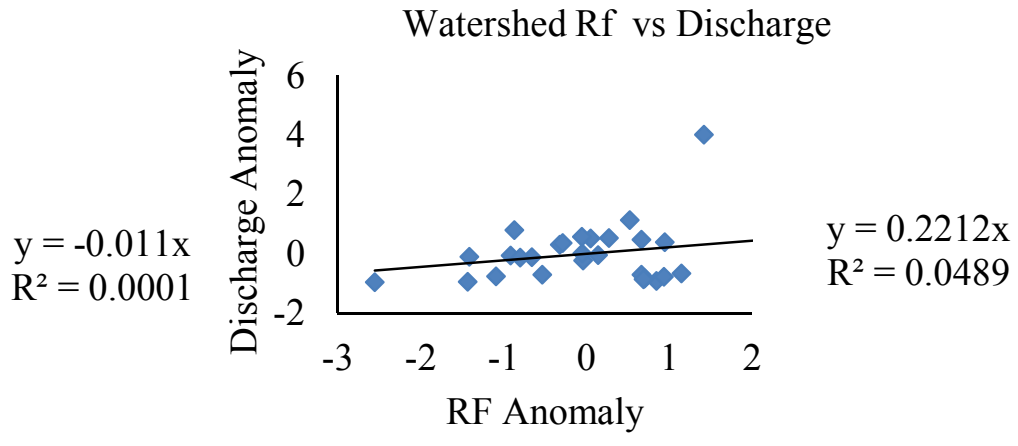

Figure 4. Relationship between rainfall and streamflow trend

\subsubsection{Temperature vs Discharge}

The relationship between temperature and discharge is indicated in Figure 7. The average temperature and discharge at Modjo river watershed indicated a negative and relatively strong correlation for three out of five stations (Figure. 7). The calculated correlation coefficients were $(-0.54,-0.48,-0.46)$ for Chefedonsa, Ejere and Aleltu stations. The rest stations such as Modjo and Debrezeit however showed a non-considerable positive correlation. The increase in average temperature at Chefedonsa, Ejere and Aleltu have resulted a decreasing trend in stream flow. The average annual temperature of Modjo River watershed has a negative correlation with the annual average discharge with a correlation coefficient of -0.54 where about $54 \%$ of decline in discharge is brought by a unit increase in temperature anomaly in the watershed. Increases in temperature of the stations has drastically decreased runoff volume which might result from increased loses of water by evapotranspiration. Supporting the findings of the study (Zhang et al., 2014) reported a significant increasing trend of annual mean temperature and potential evapotranspiration in Xitiaoxi River basin in China which were partly responsible for the significant declining trend of annual streamflow. Abeysingha et al. (2016) also indicated the increasing trend of air temperature increases the atmospheric water demand through higher evapotranspiration and contributes to the increased water loss from the basin and decreases trend in streamflow. There are studies which indicated an increase in trends of temperature causing an increasing evapotranspiration consequently causing decline in streamflow (Abdo et al., 2009, Setegn et al., 2011). 

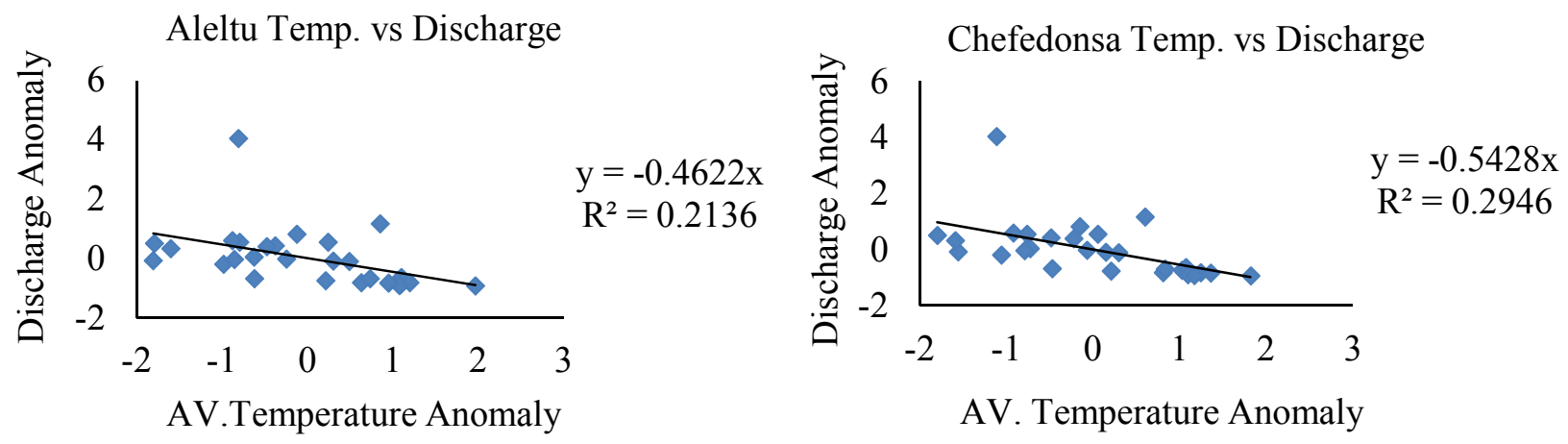

DZ Temp vs Discharge
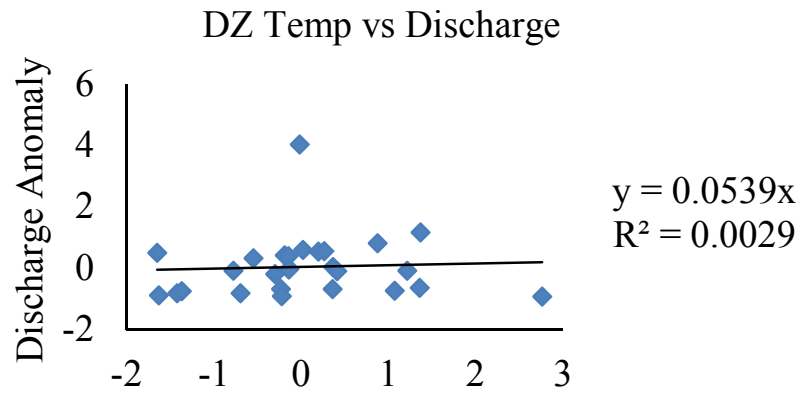

AV. Temperature Anomaly
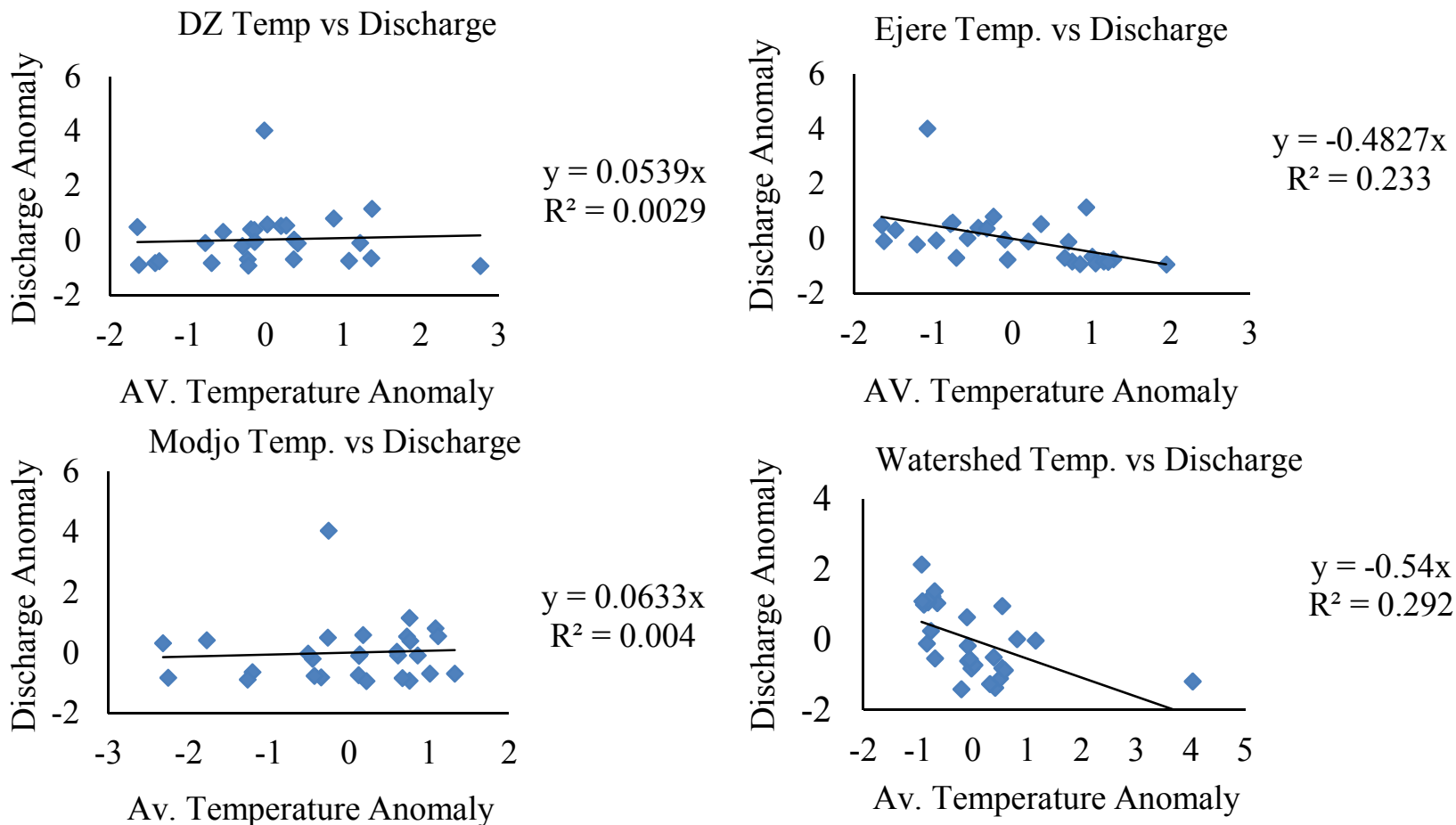

Figure 5. Relationship between temperature and streamflow trend

\section{CONCLUSIONS}

Climate change and variability is expected to trigger changes in temperature and precipitation series that would affect the flow volume and patterns in a watershed. The study conducted at Modjo River watershed revealed a significant increase in temperature during the historical (1981-2010) period. During the same period, precipitation however did not show any significant changes although numerical decline in amount was observed. Consequent to changes in temperature, stream flow reduced significantly during the analysis period owing to increased demands of evapotranspiration triggered by temperature increase. Relatively high correlation was observed between temperature and discharge than between rainfall and discharge signifying greater dependence of temperature with flow amount in the watershed. Hence, warming future will have a significant effect in the watersheds water output posing challenge on Koka water reserve for hydroelectric power. Thus, any watershed management strategy that can optimize water conservation for sustainable crop production and option that can improve flow to the reserve is vital.

Conflicts of Interest: The author declare no conflicts of interest.

Funding: This research was funded by Ethiopian Institute of Agricultural research.

Acknowledgments: The author would like to acknowledge Ethiopian Institute of Agricultural research (EIAR) for providing a post graduate study. Thanks to National Meteorological Agency of Ethiopia (NMA) and Ministry of Water, Irrigation and Electricity (MoWIE) for kindly providing data required for the present study free of charge.

\section{REFERENCES}

Abdo, K.S., Fiseha, B.M., Rientjes, T.H.M., Gieske, A.S.M., Haile, A.T., 2009. Assessment of climate change 
impacts on the hydrology of Gilgel Abay catchment in Lake Tana basin, Ethiopia. Hydrol. Process 23, 36613669.

Abeysingha, N., Singh, M., Sehgal, V., Khanna, M.\&, Pathak, S., 2016. Analysis of trends in streamflow and its linkages with rainfall and anthropogenic factors in Gomti River basin of North India. Theor. Appl. Climatol. $123,785-799$.

Ademe, F., Kibret, K., Beyene, S., Mitike, G., Getinet, M., 2019. Rainfall analysis for rain-fed farming in the Great Rift Valley Basins of Ethiopia. J. Water Clim. Chang. 10. https://doi.org/10.2166/wcc.2019.242

Assefa, K., Moges, M.A., 2018. Low Flow Trends and Frequency Analysis in the Blue Nile Basin, Ethiopia. J. Water Resour. Prot. 10, 182-203.

Bekele, D., Alamirew, T., Kebede, A., Zeleke, G., Melese, Assefa, M., 2016. Analysis of rainfall trend and variability for agricultural water management in Awash River Basin, Ethiopia. Water Clim. Chang. | 8, 127141. https://doi.org/10.2166/wcc.2016.044

Bewket, W., Conway, D., 2007. A note on the temporal and spatial variability of rainfall in the drought-prone Amhara region of Ethiopia. Int. J. Climatol. 27, 1467-1477.

Biru, Z.G., Kumar, D., 2016. Application of Soil and Water Assessment Tool Model to Estimate Runoff and Sediment Yield from Mojo Watershed. Int. J. Innov. Res. Sci. Eng. Technol. 5, 2081-2091. https://doi.org/10.15680/IJIRSET.2016.0502058

Boko, M., Niang, I., Nyong, A., Vogel, C., Githeko, A., Medany, M., Osman-Elasha, B., Tabo, R.\&, Yanda, P., 2007. Africa. In Climate Change 2007: Impacts, Adaptation and Vulnerability. Contribution of Working Group II to the Fourth Assessment Report of the Intergovernmental Panel on Climate Change (Eds M. L. Parry, O. F. Canziani, J. P. Palutikof, P. J. van der Linde. Cambridge, UK:

Buishand, T.A., 1982. Some methods for testing the homogeneity of rainfall records. J. Hydrol 58, 11-27.

FAO/UNESCO, 1995. The digital soil map of the world. Rome.

Fentaw, F., Hailu, D., Nigussie, A., 2017. Trend and Variability Analysis of Rainfall \& Stream Flow Series at Tekeze River Basin, Ethiopia. Int. J. Sci. Eng. Res. 8.

Gedefaw, M., Wang, H., Yan, D., Song, X., Yan, D., Dong, G., Wang, J., Girma, A., Ali, B.A., Batsuren, D., Al., E., 2018. Trend Analysis of Climatic and Hydrological Variables in the Awash River Basin, Ethiopia. water 10,1554 [CrossRef].

Gizaw, M.S., Biftu, G.F., Gan, T.Y., Moges, S.A., Koivusalo, H., 2017. Gizaw, M.S.; Biftu, G.F.; Gan, T.Y.; Moges, S.A.; Koivusalo, H. Potential impact of climate change on streamflow of major Ethiopian rivers. Clim. Chang. 143, 371-383. [CrossRef].

IPCC, 2007. Summary for Policymakers. In: Climate Change 2007: The Physical Science Basis. Contribution of Working Group I to the Fourth Assessment Report of the Intergovernmental Panel on Climate Change [Solomon, S., D. Qin, M. Manning, Z. Chen, M. Marquis, K.B. Ave. University Press, Cambridge, United Kingdom and New York, NY, USA.

Kassie, B.T., Rotter, R.P., Hengsdijk, H., Asseng, S., Van Ittersum, M.K., Kahiluto, H., Van Keulen, H., 2013. Climate variability and change in the Central Rift Valley of Ethiopia: challenges for rainfed crop production. J. Agric. Sci. 152, 58-74.

Kendall, M., 1975. Rank correlation methods. Griffin, London. J. Econom. 13, 245-259.

Kumar, V., Jain, S.K.\&, Singh, Y., 2010. Analysis of long-term rainfall trends in India. Hydrol. Sci. J 55, 484496.

Kundzewicz, Z.W. and, Robson, A.J., 2004. Change detection in hydrological records a review of the methodology,. Hydrol. Sci. J. 49, 7-19.

Mann, H., 1945. Nonparametric tests against trend. J. Econom. 13, 245-259.

Meehl, G.A., Stocker, T.F., Collins, W.D., Friedlingstein, P., Gaye, A.T., Gregory, J.M., Kitoh, A., Knutti, R., Murphy, J.M., Noda, A., 2007. Global climate projections. In: Climate Change 2007: The Physical Science Basis. Contribution of Working Group I to the Fourth Assessment Report of the Intergovernmental Panel on Climate Change. Cambridge University Press, Cambridge, United Kingdom and New York, NY, USA.

Mengistu, D., Bewket, W., Lal, R., 2014. Recent spatiotemporal temperature and rainfall variability and trends over the Upper Blue Nile River Basin , Ethiopia. Int. J. Climatol. 34, $2278-2292$. https://doi.org/10.1002/joc.3837

Milliman, J., Farnsworth, K., Jones, P., Xu, K., Smith, L., 2008. Climatic and anthropogenic factors affecting river discharge to the global ocean, 1951-2000. Glob Planet Chang 62, 187-194.

Muluneh, A., Biazin, B., 2015. Impact of predicted changes in rainfall and atmospheric carbon dioxide on maize and wheat yields in the Central Rift Valley of Ethiopia. Reg. Environ. Chang. 1105-1119. https://doi.org/10.1007/s10113-014-0685-x

Ngongondo, C., Xu, C.Y., Gottschalk, L., Alemaw, B., 2011. Evaluation of spatial and temporal characteristics of rainfall in Malawi: A case of data scarce region. J. Theor. Appl. Climatol. 106, 79-93.

NMA, 2007. Climate change national adaptation programme of action (NAPA) of Ethiopia: Technical Report, 
National Meteorological Agency. Addis Abeba.

Peterson, T.C., Easterling, T. and, Karl, R., 1998. Homogeneity adjustments of in-situ atmospheric climate data. Int. J. Climatol. 18, 1493-1517.

Salmi, T., Maatta, A., Anttila, P., Ruoho-Airola, T., Amnell, T., 2002. Detecting trends of annual values of atmospheric pollutants by the Mann-Kendall test and Sen's slope estimates -the Excel template application MAKESENS, Finnish meteorological Institute. Helsinki, Finland.

Seleshi, Y., Zanke, U., 2004. Recent changes in rainfall and rainy days in Ethiopia. Int. J. Climatol. 24, 973-983.

Setegn, S.G., Rayner, D., Melesse, A.M., Dargahi, B., Srinivasan, R., 2011. Impact of climate change on the hydroclimatology of Lake Tana Basin, Ethiopia. Water Resour. Res. 47, 1-13. https://doi.org/10.1029/2010WR009248

Stern, R., Rijks, D., Dale, I., Knock, J., 2006. INSTAT Climatic Guide. Statistical Service Centre. University of Reading, UK.

Tekle, A., Tadele, K., 2014. Assessment of climate change impact on water availability of bilate watershed, ethiopian rift valley basin. J. enviroment earth Sci. 4, 148-157. https://doi.org/10.1109/AFRCON.2015.7332041

Thornton, P.K., Jones, P.G., Owiyo, T.M., Kruska, R.L., Herrero, M., Kristjanson, P., Notenbaert, A., Bekele, N., Omolo, A., Orindi, V., Ochieng, A., Otiende, B., Bhadwal, S., Anantram, K., Nair, S., Kumar, V., Kelkar, U., 2006. Mapping Climate Vulnerability and Poverty in AFRICA: Report to the Department for International Development. . ILRI, Nirobi, Kenya.

Tibebe, M., Kumar, L., Koech, R., Zemadim, B., 2019. Hydro-Climatic Variability: A Characterization and Trend Study of the Awash River Basin, Ethiopia. Hydrology 6, 1-19.

Yue, S., Pilon, P., Cavadias, G., 2002. Power of Mann-Kendall and Spearmans rho test for detecting monotonic trends in hydrological series. J. Hydrol. 259, 254-271.

Zhang, C., Zhang, B., Li, W., Liu, M., 2014. Response of streamflow to climate change and human activity in Xitiaoxi river basin in China. Hydrol Process 28, 43-50. 